\title{
KONVERSI LAHAN SAWAH DI INDONESIA DAN PENGARUHNYA TERHADAP KEBIJAKAN HARGA PEMBELIAN PEMERINTAH (HPP) GABAH/BERAS
}

\section{FIELD LAND CONVERSION IN INDONESIA AND ITS EFFECT ON THE POLICY OF THE GOVERNMENT PURCHASE PRICE (HPP) OF GRAINS/RICE}

\author{
Erni Purbiyanti ${ }^{* 1}$, Muhammad Yazid ${ }^{* *}$, dan Indri Januarti**) \\ *) Program Studi Agribisnis Fakultas Pertanian Universitas Sriwijaya \\ Jl. Raya Palembang-Prabumulih Km. 32 Inderalaya, Ogan Ilir, Sumatera Selatan
}

\begin{abstract}
Conversion of paddy fields in Indonesia is quite alarming, reaching an average area of 10 thousand hectares per year. Various regulations have been created and assigned; however, they are considered not to effectively reduce the rate of conversion of the existing paddy fields. The paddy field conversion has brought about negative impacts on the national food security. To overcome these, besides issuing the government regulations to reduce the rate of paddy field conversion, the government has also set a number of policies to boost rice production and to improve the welfare of farmers. One policy is the pricing policy by the Government Purchase Price (grains/rice). This study aimed to analyze the paddy field conversion in Indonesia and its effect on the Government Purchase Price (grains/rice). The data used in this research were the dynamic time series data from the years of 1990-2010, with the consideration of the upward trend in paddy field conversion in Indonesia. The models built an econometric model of simultaneous equations consisted of 41 equations (19 structural equations and 22 identity equations) or in other words, the model consisted of 41 endogenous variables. The results showed that the real prices (grains/rice) of the government purchases have inelastic responses to the changes of all explanatory variables in the short and long terms. The conversion of paddy fields in Indonesia has not only reduced the existing rice production capacity but also has affected the government purchase price policy (grains/rice). The government requires to implement the multi qualities of the government purchasing pries (HPP) for both grains and rice.
\end{abstract}

Keywords: rice, grain, government purchase price, paddy field conversion

\begin{abstract}
Abstrak: Konversi lahan sawah di Indonesia cukup mengkhawatirkan, yaitu mencapai luasan rata-rata 10 ribu hektar per tahun. Berbagai peraturan sudah dibuat dan ditetapkan, namun dinilai belum efektif menekan laju konversi lahan sawah yang ada. Konversi lahan sawah berdampak negatif terhadap ketahanan pangan nasional. Untuk mengatasi itu semua, selain mengeluarkan peraturan pemerintah untuk menekan laju konversi lahan sawah, pemerintah juga telah menetapkan berbagai kebijakan untuk meningkatkan produksi padi dan juga untuk meningkatkan kesejahteraan petani. Salah satunya melalui kebijakan harga melalui Harga Pembelian Pemerintah (HPP) gabah/beras. Penelitian ini bertujuan untuk menganalisis konversi lahan sawah di Indonesia dan pengaruhnya terhadap Harga Pembelian Pemerintah (HPP) gabah/ beras. Jenis data yang digunakan dalam penelitian ini adalah data deret waktu dari tahun 19902010, yang bersifat dinamik, dengan pertimbangan tren peningkatan konversi lahan sawah di Indonesia. Model yang dibangun merupakan model ekonometrika persamaan simultan, yang terdiri dari: 41 persamaan (19 persamaan struktural dan 22 persamaan identitas) atau dengan kata lain model terdiri dari 41 peubah endogen. Hasil penelitian menunjukkan bahwa harga riil (gabah) pembelian pemerintah memiliki respon inelastis terhadap peubah: perubahan harga riil beras impor Indonesia, pendapatan riil nasional Indonesia dan nilai tukar tahun sebelumnya; baik dalam dalam jangka pendek dan jangka panjang. Konversi lahan sawah di Indonesia tidak saja menurunkan kapasitas produksi padi yang ada. Namun lebih jauh dari itu, konversi lahan sawah juga memengaruhi kebijakan harga pembelian pemerintah (gabah/beras). pemerintah perlu mengimplementasikan harga pembelian pemerintah (HPP) multikualitas masing-masing untuk gabah dan beras.
\end{abstract}

Kata kunci: beras, gabah, harga pembelian pemerintah, konversi lahan sawah

\footnotetext{
${ }^{1}$ Corresponding author:

Email: fathiyyah_qb@yahoo.co.id
} 


\section{PENDAHULUAN}

Berdasarkan data luas baku lahan sawah dalam tiga dekade terakhir, rata-rata konversi lahan sawah yang terjadi di Jawa sebesar 8.346,65 ha/tahun dan di luar Jawa sebesar 2.269,75 ha/tahun sehingga luas baku lahan sawah terkonversi rata-rata setiap tahunnya mencapai luasan 10.616,4 ha/tahun (Purbiyanti, 2013). Walaupun tidak semasif di Jawa, konversi lahan sawah di luar Jawa pun seakan tidak bisa dihindari. Kondisi ini semakin mengkhawatikan, mengingat pesatnya pertumbuhan ekonomi di luar Jawa saat ini dan laju pertumbuhan penduduk di luar Jawa yang masih mencapai $1,36 \%$ dalam 10 tahun terakhir. Sumatera Selatan yang merupakan salah satu lumbung pangan nasional di luar Jawa pun tak lepas dari kondisi ini (Purbiyanti et al. 2013).

Laju konversi lahan yang tidak terkendali dan hambatan dalam peningkatan produktivitas padi (levelingoff) merupakan faktor utama yang melemahkan program ketahanan pangan (Irawan, 2005). Penelitian Adimiharja et al. (2004) juga menyebutkan bahwa penurunan produksi padi secara nasional akibat konversi lahan sawah masih sulit diimbangi dengan upaya peningkatan perluasan areal sawah di luar Jawa. Sebagaimana hasil perhitungan menunjukkan bahwa untuk mensubstitusi hilangnya produksi padi setiap 1 ha lahan sawah beririgasi di Jawa diperlukan sekitar 4-5 ha lahan sawah baru di luar Jawa. Hal ini dikarenakan produktivitas padi di Jawa dan luar Jawa berbeda. Data BPS (2011) menunjukkan bahwa produktivitas padi di Jawa lebih tinggi (5,58 ton/ha) dibandingkan produktivitas di luar Jawa (4,21 ton/ ha). Peningkatan produktivitas tidak serta-merta dapat menyelesaikan permasalahan perbedaan produktivitas ini. Peningkatan produktivitas usaha tani padi ini sulit dilakukan akibat stagnasi inovasi teknologi, yang ditandai oleh laju kenaikan produktivitas yang semakin berkurang. Hal ini ditunjukkan oleh laju produktivitas padi di Jawa yang mengalami penurunan terutama pada tahun 2008-2010, yaitu sebesar 3,31; 2,61; dan $-0,56 \%$. Laju produktivitas padi di luar Jawa juga mengalami penurunan dalam kurun tiga tahun tersebut, yaitu sebesar 2,59, 2,5 dan 0,9\%.

Data empiris membuktikan bahwa semakin tinggi produktivitas lahan sawah yang terkonversi, semakin tinggi pula kerugian yang terjadi. Kerugian itu berupa hilangnya kesempatan kapasitas untuk memproduksi padi antara 4,5-12,5 ton/ha/tahun, tergantung pada kualitas lahan sawah yang bersangkutan (Sumaryanto et al. 2006). Perhitungan kerugian ini hanya berdasarkan kesempatan produksi padi yang hilang, belum memperhitungkan kerugian sosial, budaya dan lingkungan. Konversi lahan sawah di Jawa yang hampir tiga kali lipat lebih besar dengan produktivitas padi yang juga lebih tinggi dibandingkan di luar Jawa, merupakan ancaman serius bagi ketersediaan produksi pangan dalam negeri. Terlebih Jawa merupakan penghasil sekitar $60 \%$ produksi padi nasional. Kondisi ini semakin memperparah dampak konversi lahan sawah, disamping dampaknya yang bersifat permanen, kumulatif dan progresif (Irawan, 2005).

Selama ini peraturan/perundangan yang berkaitan dengan konversi lahan pertanian sudah banyak dibuat. Setidaknya ada 11 peraturan/perundangan yang berkenaan dengan masalah ini. Namun, hingga saat ini pengendalian konversi lahan pertanian belum optimal. Permasalahan di lapangan terlalu kompleks sehingga kebijakan yang dibuat haruslah sistemik. Implementasi peraturan/perundangan tidak efektif karena tidak didukung oleh data dan sikap proaktif yang memadai. Tiga kendala mendasar yang menjadi alasan peraturan pengendalian konversi lahan sulit dilaksanakan adalah 1) kebijakan yang kontradiktif; 2) cakupan kebijakan yang terbatas; dan 3) kendala konsistensi perencanaan (Nasoetion, 2003).

Selain beberapa instrumen kebijakan ekonomi sektor pertanian yang telah dijelaskan sebelumnya, kebijakan harga (input maupun output) juga sering diimplementasikan pemerintah untuk melindungi petani. Salah satunya adalah kebijakan harga output yang dikenal dengan kebijakan Harga Dasar yang bertujuan melindungi petani dari turunnya harga secara drastis pada saat panen raya (suplai melimpah). Kebijakan Harga Dasar ini ditetapkan oleh pemerintah dan telah mengalami perubahan istilah penamaan, seperti: Harga Dasar Gabah (HDG), Harga Dasar Pembelian Gabah (HDPG), Harga Dasar Pembelian Pemerintah (HDPP) dan Harga Pembelian Pemerintah (HPP) merupakan hal yang sama dalam menyebutkan harga dasar dengan konsep yang sama. Pemerintah melalui Inpres No. 9 Tahun 2002, telah mengubah kebijakan harga dasar menjadi kebijakan (tunggal) HPP gabah/beras per 1 Januari 2003. Setelah itu, berbagai Inpres diterbitkan oleh pemerintah untuk jadi acuan penetapan HPP di lapangan bagi Bulog/Dolog Sub Divre di beberapa daerah (Intan et al. 2012). Namun demikian, menurut Simatupang (2003), sebenarnya ada 
perbedaan yang sangat mendasar dari perubahan nama tersebut. Perbedaan antara HDG dan HPP disajikan pada Tabel 1.

Berbeda dengan HDG, HPP sebenarnya adalah harga pembelianpetaniuntukmengisistokBulogsebesar 8-10\% dari total produksi nasional. Ini merupakan konsekuensi pasca-penandatanganan perjanjian pertanian WTO pada tahun 1995 sehingga terjadi liberalisasi perdagangan dengan indikator: a) pembebasan bea masuk impor beras sampai $0 \%$; b) pencabutan status Bulog sebagai lembaga penyangga; c) pencabutan subsidi input dan liberalisasi tataniaga pupuk tahun 1998. Perjanjian WTO tersebut memberi dampak terutama pada perubahan fungsi Bulog dan perubahan HDG menjadi HPP. Perubahan nama dari HDG menjadi HPP diduga tidak signifikan memengaruhi proses pembentukan harga beras. Harga beras yang ada diduga merupakan hasil dari mekanisme pasar sehingga kebijakan penetapan HPP beras ini dinilai perlu dipertimbangkan kembali. Berdasarkan paparan, peneliti tertarik untuk melakukan analisis kaitan antara konversi lahan sawah di Indonesia secara luas, khususnya terhadap kebijakan penetapan Harga Pembelian Pemerintah (HPP) gabah/beras yang ada.

\section{METODE PENELITIAN}

Jenis data yang digunakan dalam penelitian ini adalah data deret waktu dari tahun 1990-2010 yang bersifat dinamik dengan pertimbangan tren peningkatan konversi lahan sawah di Indonesia. Khusus konversi lahan sawah, data yang digunakan adalah data konversi lahan sawah netto. Data net konversi lahan sawah yang bernilai positif diasumsikan secara netto tidak terjadi konversi lahan sawah sehingga bernilai nol dan selanjutnya ditulis 0,001 untuk memudahkan pengolahan data. Data yang digunakan bersumber dari beberapa instansi yang terkait, yaitu Kementerian Pertanian (Kementan), Badan Urusan Logistik (Bulog), Kementerian Perdagangan (Kemendag), Badan Pusat Statistik (BPS) dan Pusat Sosial Ekonomi dan Kebijakan Pertanian (PSEKP). Penelitian ini juga melakukan pengambilan data dari beberapa website resmi, seperti: Food Agricultural Organization (FAO), World Bank dan berbagai publikasi lainnya yang terkait.Semua harga nominal merupakan harga rata-rata tertimbang, selanjutnya dideflasi dengan indeks harga pada tahun dasar $(2005=100)$ sehingga diperoleh harga riil yang sudah memperhitungkan inflasi pada tahun yang bersangkutan.
Model ekonometrika yang dibangun merupakan model persamaan simultan, yang akan mengkaitkan berbagai peubah dalam blok konversi lahan sawah dengan blok ketersediaan pangan dan blok akses pangan. Model ketersediaan dan akses pangan di Indonesia yang telah dirumuskan ini terdiri dari: 41 persamaan (19 persamaan struktural dan 22 persamaan identitas) atau dengan kata lain model terdiri dari 41 peubah endogen (G). Peubah predetermined dalam model berjumlah 74 peubah yang terdiri dari 41 peubah eksogen dan 33 lag peubah endogen. Oleh karena itu, total peubah yang ada di dalam model (K) berjumlah 115 peubah, dengan jumlah peubah predetermined terbanyak dalam suatu persamaan (M) adalah sebanyak 7 peubah. Maka berdasarkan order condition criteria, setiap persamaan di dalam model ini adalah teridentifikasi secara berlebih (over-identified). Metode pendugaan model yang dapat dilakukan adalah metode 2-SLS (Two Stage Least Squares). Metode 2-SLS lebih tepat digunakan untuk analisis simultan, dimana dalam analisis ini semua peubah diperhitungkan sebagai suatu sistem secara menyeluruh (Pyndick \& Rubinfeld, 1998). Penghitungan parameter pendugaan persamaan struktural dalam model dilakukan dengan menggunakan program komputer SAS/ETS (Statistical Analysis System/Econometric Time Series) versi 9.1.Penelitian ini menguji tentang beberapa asumsi dari metode pendugaan OLS, yaitu sebagai berikut:

\section{a. Serial Korelasi (Autocorrelation)}

Serial korelasi (autocorrelation) didefinisikan sebagai korelasi yang terjadi antara anggota-anggota dari serangkaian pengamatan yang tersusun dalam rangkaian waktu (data time series) atau yang tersusun dalam rangkaian ruang (data cross section). Pada umumnya banyak terjadi pada kasus data time series. Sebagai pengganti untuk mengetahui apakah serial korelasi (autocorrelation) atau tidak dalam setiap persamaan, maka digunakan uji statistik dh (Durbin-h statistic) sebagai berikut:

$$
h=\left(1-\frac{D w}{2}\right) \sqrt{\frac{T}{1-T[\operatorname{Var}(\beta)]}}
$$

Keterangan: h (Angka statistik Durbin-h); Dw (Durbin-w statistik); T (Jumlah observasi); Var $(\beta)$ (Varian koefisien regresi untuk lagged dependent variable). 
Tabel 1. Perbedaan antara HDG dan HPP

\begin{tabular}{lll}
\hline \multicolumn{1}{c}{ Komponen } & \multicolumn{1}{c}{ HDG } & \multicolumn{1}{c}{ HPP } \\
\hline Pembentukan harga & $\begin{array}{l}\text { Pemerintah melalui Bulog membeli } \\
\text { kelebihan pasokan dalam jumlah besar } \\
\text { sehingga petani mendapatkan harga minimal } \\
\text { tidak dibawah HDG. }\end{array}$ & $\begin{array}{l}\text { Pemerintah tidak menjamin bahwa harga } \\
\text { gabah yang diterima petani selalu berada } \\
\text { di atas HPP yang ditetapkan. }\end{array}$ \\
& $\begin{array}{l}\text { Pemerintah berkewajiban dan bertanggung } \\
\text { jawab untuk menjamin harga dasar gabah } \\
\text { minimum di tingkat petani. }\end{array}$ & $\begin{array}{l}\text { Pemerintah tidak lagi berkewajiban \& } \\
\text { bertanggung jawab untuk menjamin harga } \\
\text { dasar gabah minimum di tingkat petani. }\end{array}$ \\
& $\begin{array}{l}\text { Berlaku di tingkat petani sehingga Bulog } \\
\text { menanggung biaya angkut, transportasi, dll. }\end{array}$ & $\begin{array}{l}\text { Berlaku di gudang Bulog. Bulog tidak } \\
\text { menanggung biaya angkut, transportasi, } \\
\text { dll, sehingga HPP yang ditetapkan }\end{array}$ \\
& & $\begin{array}{l}\text { pemerintah bukanlah HPP yang diterima } \\
\text { petani, melainkan harga yang diterima } \\
\text { pedagang rekanan Bulog. }\end{array}$ \\
\hline
\end{tabular}

Apabila $\mathrm{h}_{\text {hitung }}$ lebih kecil dari nilai kritis $\mathrm{h}$ dari tabel distribusi normal $\left(\mathrm{h}_{\text {hitung }}<\mathrm{h}_{\text {tabel }}\right)$ maka dalam persamaan tidak mengalami serial korelasi (autocorrelation) Jika menggunakan taraf probabilitas $\alpha=5 \%$, diketahui $-1,96 \leq \mathrm{h}_{\text {hitung }} \leq 1,96$ maka dapat disimpulkan bahwa persamaan tidak mengalami serial korelasi. Akan tetapi jika nilai $\mathrm{h}_{\text {hitung }}<-1,96$ maka disimpulkan bahwa persamaan mengalami autokorelasi negatif. Sebaliknya, jika diperoleh nilai $h_{\text {hitung }}>1.96$ maka disimpulkan bahwa persamaan mengalami autokorelasi positif. Selain itu, uji Durbin-h ini tidak valid ketika lebih dari 1, karena tidak dapat menghitung nilai akar kuadrat negatif (Pindyck dan Rubinfeld, 1998).

\section{b. Multikolinieritas}

Suatu hubungan linier antara dua atau lebih independent variable disebut sebagai multicollinearity. Pengujian terhadap multikolinieritas dilakukan dengan melihat nilai variance inflation factor (VIF) yang terdapat pada prosedur PROC REG dalam program SAS. Nilai VIF dapatdihasilkan setelahmenuliskanpernyataan MODEL pada PROC REG kemudian menggunakan pilihan VIF setelah tanda slash (/). Masalah multikolinieritas pada suatu model persamaan linier regresi berganda akan selalu ditemukan. Masalah multikolinieritas dinilai serius jika nilai VIF lebih besar dari 10. Sebaliknya, dinilai tidak serius jika nilai VIF lebih kecil dan atau sama dengan 10 (Sitepu dan Sinaga, 2006).

Validasi model dilakukan dengan tujuan mengetahui tingkat representasi model dibandingkan dengan dunia nyata sebagai dasar untuk melakukan simulasi, juga untuk mengetahui apakah model cukup valid jika dibuat suatu simulasi alternatif kebijakan atau nonkebijakan dan peramalan. Berbagai kriteria statistik dapat digunakan untuk validasi model ekonometrika dengan membandingkan nilai-nilai aktual dan dugaan peubah-peubah endogen (Intriligator, 1978). Keeratan arah (slope) antara aktual dengan hasil yang disimulasi dapat dilihat dari nilai koefisien determinasinya $\left(\mathrm{R}^{2}\right)$. Semakin besar nilai $\mathrm{R}^{2}$ tersebut berarti semakin besar proporsi variasi perubahan peubah endogen yang dapat dijelaskan oleh variasi dalam peubah penjelas sehingga model semakin baik. Prosedur analisis yang dilakukan meliputi tahapan berikut ini (Gambar 1). Sementara itu, langkah-langkah dalam estimasi model selengkapnya pada Gambar 2.

Beberapa persamaan simultan dalam model ekonometrika yang dibangun adalah sebagai berikut:

$$
\Delta \mathrm{KLSI}_{\mathrm{t}}=\mathrm{LBSI}_{\mathrm{t}}-\mathrm{LBSI}_{\mathrm{t}-1}
$$

Keterangan: $\Delta$ KLSI $_{t}$ (Perubahan konversi lahan sawah di Indonesia (ha)); LBSI (Luas baku sawah di Indonesia (ha)); LBSI $_{\mathrm{t}-1}$ ( Lag luas baku sawah di Indonesia (ha)).

$$
\begin{aligned}
\text { LAPI }_{\mathrm{t}}= & \mathrm{a}_{0}+\mathrm{a}_{1}\left(\operatorname{HGTTIR}_{\mathrm{t}} / \operatorname{HGTTIR}_{\mathrm{t}-1}\right)+\mathrm{a}_{2} \operatorname{HJTPIR}_{\mathrm{t}}+ \\
& \mathrm{a}_{3} \operatorname{HUREIR}_{\mathrm{t}}+\mathrm{a}_{4} \operatorname{KLSI}_{\mathrm{t}-1}+\mathrm{a}_{5} \operatorname{IPI}_{\mathrm{t}}+\mathrm{a}_{6} \operatorname{LAPI}_{\mathrm{t}-1} \\
& +\mathrm{U}_{1}
\end{aligned}
$$

Keterangan: LAPJ (Luas areal panen padi di Jawa

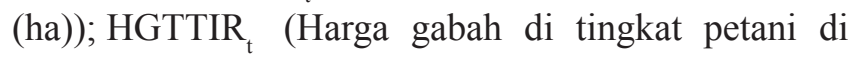
Indonesia $(\mathrm{Rp} / \mathrm{kg})$, dideflasi dengan indeks harga pedagang besar Indonesia tahun dasar $(2005=100)$ ); HGTTIR $_{\mathrm{t}-1}$ (Lag harga gabah di tingkat petani di Indonesia $(\mathrm{Rp} / \mathrm{kg})$, dideflasi dengan indeks harga pedagang besar Indonesia tahun dasar $(2005=100)$ ); HJTPIR $_{t}$ (Harga jagung di tingkat produsen di Indonesia $(\mathrm{Rp} / \mathrm{kg})$, dideflasi dengan indeks harga pedagang besar Indonesia tahun dasar $(2005=100)$ ); 
HUREIR $_{\mathrm{t}}$ (Harga pupuk Urea di Indonesia (Rp/kg), dideflasi dengan indeks harga konsumen Indonesia

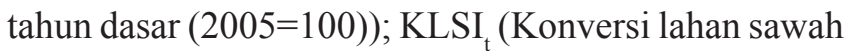
di Indonesia (ha)); IPI (Intensitas pertanaman padi di

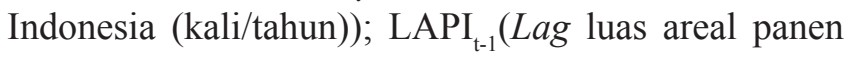
padi di Indonesia (ha)); U1 (Peubah pengganggu). Tanda dan besaran parameter dugaan yang diharapkan adalah $\mathrm{a}_{1}, \mathrm{a}_{5}>0 ; \mathrm{a}_{2}, \mathrm{a}_{3}, \mathrm{a}_{4}<0$; dan $0<\mathrm{a}_{6}<1$;

YPPI $_{t}=b_{0}+b_{1}\left(\right.$ HGTTIR $_{t} /$ HUREIR $\left._{t}\right)+b_{2}$ JUREI $_{t}+$ $\mathrm{b}_{3} \mathrm{CHI}_{\mathrm{t}}+\mathrm{b}_{4} \mathrm{LASII}_{\mathrm{t}}+\mathrm{b}_{5}$ YPPI $_{\mathrm{t}-1}+\mathrm{U}_{2}$

Keterangan: YPPI (Produktivitas padi di Indonesia (ton/ha)); JUREI (Jumlah penggunaan pupuk Urea (kg/ha)); CHI (Rata-rata curah hujan di Indonesia (mm/ tahun)); LASII (Luas areal irigasi di Indonesia (ha)); YPPI $_{\mathrm{t}-1}$ (Lag produktivitas padi di Indonesia (ton/ha)); $\mathrm{U}_{2}$ (Peubah pengganggu). Tanda dan besaran parameter dugaan yang diharapkan adalah $\mathrm{b}_{1}, \mathrm{~b}_{2}, \mathrm{~b}_{3}, \mathrm{~b}_{4}>0$; dan $0<$ $\mathrm{b}_{5}<1$.

$$
\mathrm{PPDI}_{\mathrm{t}}=\mathrm{LAPI}_{\mathrm{t}} * \mathrm{YPPI}_{\mathrm{t}}
$$

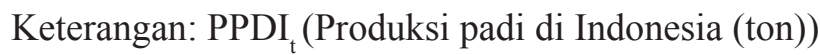

$$
\mathrm{PPDIPK}_{\mathrm{t}}=\mathrm{PPDI}_{\mathrm{t}} / \mathrm{JPDKI}_{\mathrm{t}}
$$

Keterangan: PPDIPK $_{t}$ (Produksi padi di Indonesia per kapita (ton)); JPDKLJ (Jumlah penduduk di luar Jawa (jiwa))

$$
\operatorname{PBRI}_{t}=\mathrm{PBRJ}_{t}+\mathrm{PBRLJ}_{t}
$$

Keterangan: PBRI (Produksi beras di Indonesia (ton)); $\mathrm{AK}_{\mathrm{t}}$ (Angka konversi).

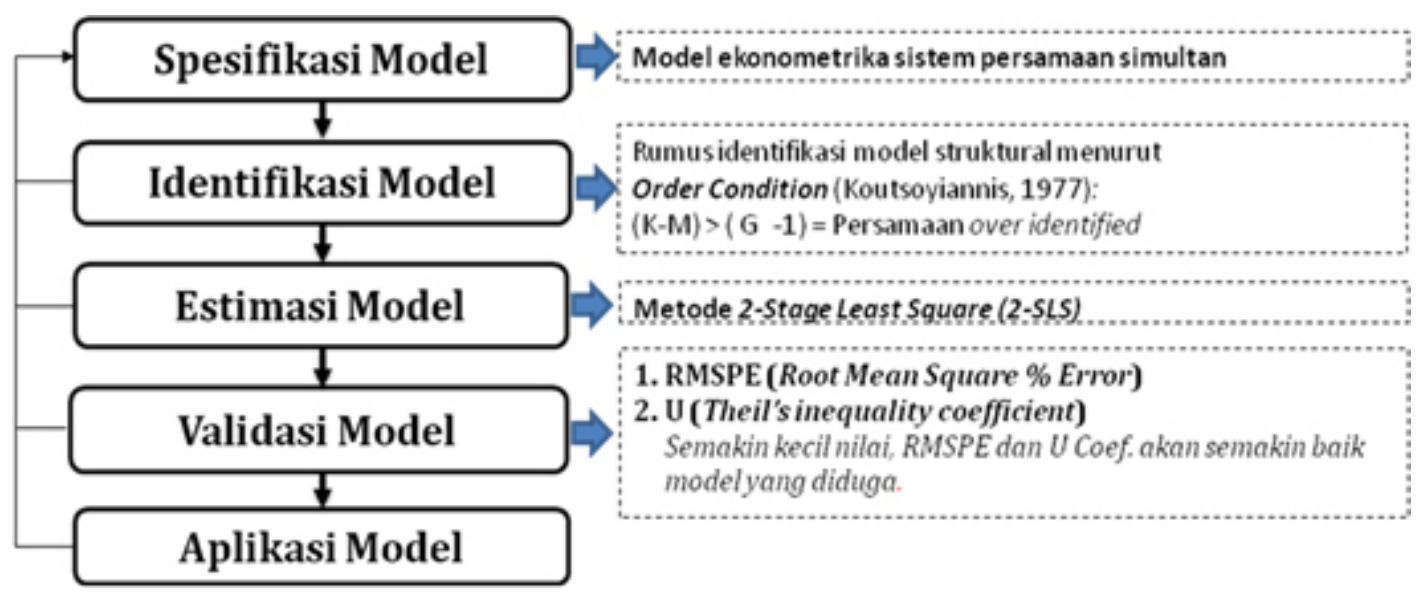

Gambar 1. Prosedur analisis

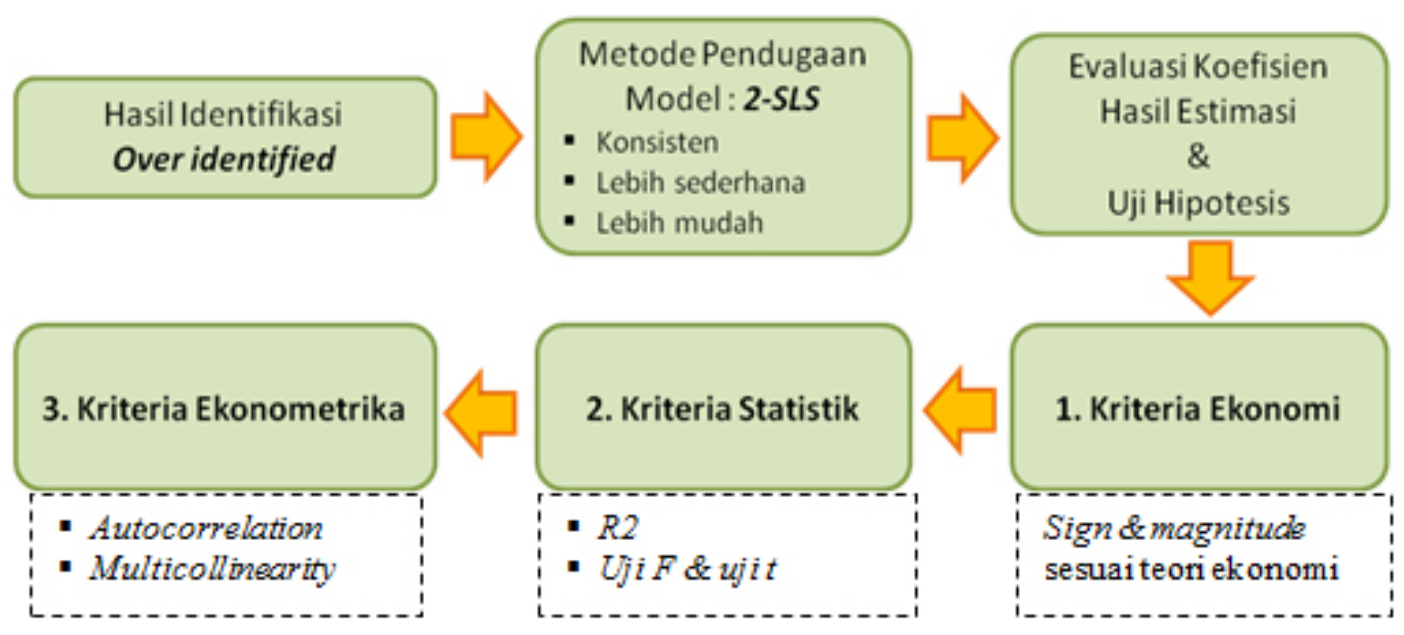

Gambar 2. Bagan alir langkah-langkah dalam estimasi model 
$\mathrm{HPPGR}_{\mathrm{t}}=\mathrm{c}_{0}+\mathrm{c}_{1} \mathrm{HMBIR}_{\mathrm{t}}+\mathrm{c}_{2}$ GDPIR $_{\mathrm{t}}+\mathrm{c}_{3}$ ERIR $_{\mathrm{t}-1}+$ $\mathrm{c}_{4} \mathrm{HPPGR}_{\mathrm{t}-1}+\mathrm{U}_{3}$

Keterangan: $\mathrm{HPPGR}_{\mathrm{t}}$ (Harga riil pembelian pemerintah (gabah/beras) dalam $\mathrm{Rp} / \mathrm{kg}$, dideflasi dengan Indeks Harga Konsumen Indonesia (tahun dasar 2005=100)); GDPIR $_{\mathrm{t}}$ (Pendapatan nasional (Rp), dideflasi dengan Indeks Harga Konsumen Indonesia (tahun dasar 2005=100)); ERIR $_{\mathrm{t}-1}(\mathrm{Lag}$ nilai tukar rupiah terhadap US dollar (Rp/US\$), dideflasi dengan Indeks Harga Konsumen Indonesia (tahun dasar 2005=100); HPPGR $_{\mathrm{t}-1}$ (Lag harga (gabah) pembelian pemerintah $(\mathrm{Rp} / \mathrm{kg})$, dideflasi dengan Indeks Harga Konsumen Indonesia (tahun dasar 2005=100)) $\mathrm{U}_{3}$ (Peubah pengganggu). Tanda dan besaran parameter dugaan yang diharapkan adalah $\mathrm{c}_{1}, \mathrm{c}_{2}, \mathrm{c}_{3}>0$ dan $0<\mathrm{c}_{4}<1$.

$$
\begin{gathered}
\operatorname{HGTTIR}_{\mathrm{t}}=\mathrm{p}_{0}+\mathrm{p}_{1} \operatorname{HPPGR}_{\mathrm{t}}+\mathrm{p}_{2} \mathrm{MPBI}_{\mathrm{t}}+\mathrm{p}_{3}\left(\mathrm{PPDI}_{\mathrm{t}}-\right. \\
\left.\operatorname{PPDI}_{\mathrm{t}-1}\right)+\mathrm{p}_{4} \mathrm{~T}_{\mathrm{t}}+\mathrm{U}_{4}
\end{gathered}
$$

Keterangan: $\mathrm{MPBJ}_{\mathrm{t}-1}($ Marjin pemasaran beras di Jawa $(\mathrm{Rp} / \mathrm{kg})$ ); MPBLJ $_{\mathrm{t}-1}($ Marjin pemasaran beras di luar Jawa $(\mathrm{Rp} / \mathrm{kg})$ ); PPDJ ${ }_{\mathrm{t}-1}$ ( Lag produksi padi di Jawa (ton)); PPDLJ $\mathrm{t}_{\mathrm{t}-1}$ (Lag produksi padi di luar Jawa (ton)); PPDI $_{\mathrm{t}-1}$ (Lag produksi padi di Indonesia (ton)); $\mathrm{U}_{4}$ (Peubah pengganggu). Tanda dan besaran parameter dugaan yang diharapkan adalah $\mathrm{d}_{1}, \mathrm{~d}_{4}>0$ dan $\mathrm{d}_{2}, \mathrm{~d}_{3}<0$.

\section{HASIL}

Secara umum, hasil pendugaan model ketersediaan dan akses pangan di Indonesia cukup baik dilihat dari kriteria ekonomi, statistik dan ekonometrika. Kriteria ekonomi sebagai 'a priori criteria' ditentukan oleh prinsip-prinsip yang sesuai dengan kriteria ekonomi, yang mengacu pada arah dan besaran (sign and magnitude). Berdasarkan kriteria ini seluruh arah dan besaran sesuai dengan teori ekonomi. Adapun berdasarkan kriteria statistika yang merupakan firstorder test, hasil pendugaan model menunjukkan bahwa sebanyak 89,47\% (17 persamaan) dari 19 persamaan struktural mempunyai nilai koefisien determinasi $\left(\mathrm{R}^{2}\right)$ berkisar $0,60022-0,98658$, yang berarti secara umum kemampuan peubah-peubah penjelas (predetermined variable) yang ada di dalam persamaan perilaku untuk menjelaskan keragaman nilai peubah endogen (endogenous variable) cukup tinggi. Besarnya nilai probabilitas $|\mathrm{F}|$ yang kurang dari 0,05 menunjukkan bahwa peubah-peubah penjelas yang dimasukkan dalam setiap persamaan perilaku secara bersama- sama berpengaruh kuat terhadap keragaman peubah endogennya, berbeda nyata pada taraf probabilitas $1-5 \%$.

Selain itu, pengujian terhadap multikolinieritas dilakukan dengan melihat nilai variance inflation factor (VIF). Masalah multikolinieritas pada suatu model persamaan linier regresi berganda akan selalu ditemukan, tetapi ada yang serius dan ada yang tidak serius. Masalah multikolinieritas dinilai serius jika nilai VIF lebih besar dari 10, sebaliknya dinilai tidak serius jika nilai VIF lebih kecil dan atau sama dengan 10 (Sitepu dan Sinaga, 2006). Hasil pengujian diketahui bahwa semua persamaan perilaku dalam model tidak mengalami multi-kolinieritas secara serius. Hal ini ditunjukkan dari nilai VIF yang kurang dari 10. Secara keseluruhan dapat disimpulkan bahwa hasil pendugaan model representatif untuk menggambarkan fenomena ketersediaan pangan di Indonesia.

Hasil pendugaan pada persamaan luas areal panen padi di Indonesia menghasilkan koefisien determinasi $\left(\mathrm{R}^{2}\right)$ sebesar $90 \%$, yang berarti peubah penjelas yang terdiri dari rasio harga riil gabah di tingkat petani di Indonesia, harga riil jagung di tingkat produsen di Indonesia, harga riil pupuk Urea di Indonesia, lag konversi lahan sawah di Indonesia, intensitas pertanaman di Indonesia, dan lag luas areal panen padi di Indonesia sebesar 90\% mampu secara bersama-sama menjelaskan keragaman nilai peubah endogennya, sedangkan sisanya sebesar $10 \%$ dijelaskan peubah di luar persamaan. Semua peubah penjelas mempunyai arah dan besaran nilai parameter dugaan sesuai harapan (Tabel 2).

Berdasarkan fenomena ini dapat disimpulkan bahwa kebijakan harga riil gabah di tingkat petani dan harga riil pupuk Urea yang diimplementasikan pemerintah selama ini dinilai belum mampu menjadi insentif bagi petani untuk meningkatkan luas areal pertanaman padinya, tanpa didukung adanya kebijakan eksternal lain di luar persamaan, seperti teknologi dan kelembagaan. Maraknya konversi lahan sawah yang terjadi di Indonesia akan mengurangi luas baku lahan sawah yang kemudian berdampak terhadap penurunan luas areal panen padi (dengan asumsi intensitas pertanaman tetap). Hal ini karena luas areal panen padi dipengaruhi oleh luas baku sawah dan intensitas pertanamannya. Luas areal panen padi yang menurun akan berakibat terhadap menurunnya produktivitas dan produksi padi. Mengingat beras masih menjadi makanan pokok mayoritas masyarakat Indonesia maka penurunan 
produksi padi akan mengurangi ketersediaan beras di Indonesia. Untuk itu, pemerintah perlu menutupi kekurangan itu melalui impor. Peningkatan jumlah beras impor diikuti dengan peningkatan harga riil beras impor yang harus dibayar pemerintah. Peningkatan jumlah beras impor ini akan mengakibatkan peningkatan jumlah ketersediaan beras domestik. Hal ini akan menurunkan harga riil eceran beras domestik dan harga riil gabah di tingkat petani. Untuk itu, pemerintah perlu menjaga harga riil gabah di tingkat petani melalui penetapan harga riil pembelian pemerintah (gabah/ beras). Penetapan harga riil pembelian pemerintah (gabah/beras) ini diharapkan mampu menjadi insentif bagi petani untuk meningkatkan produktivitas padi mereka.
Adapun perilaku harga riil pembelian pemerintah (gabah/beras) dipengaruhi oleh harga riil beras impor Indonesia (sebagai transmisi harga dan proksi dari penawaran beras), pendapatan nasional riil (dalam hal ini sebagai proksi dari permintaan beras di Indonesia), lag nilai tukar riil rupiah terhadap US dollar, dan lag harga riil pembelian pemerintah (gabah/beras). Keempat peubah ini secara bersama-sama belum mampu menjelaskan keragaman nilai peubah harga riil pembelian pemerintah (gabah/beras) yang ditunjukkan oleh nilai $\mathrm{R}^{2}$ sebesar 47 ; sedangkan sisanya (53\%) dijelaskan oleh peubah di luar persamaan. Nilai koefisien determinasi yang kurang dari 60\% ini dikarenakan keterbatasan data peubah penjelas lainnya yang tersedia sehingga baru sebatas empat peubah saja yang dimasukkan dalam persamaan. Namun demikian, semua peubah penjelas mempunyai arah dan besaran nilai parameter dugaan sesuai harapan (Tabel 3).

Tabel 2. Hasil pendugaan parameter luas areal panen padi di Indonesia (LAPI)

\begin{tabular}{|c|c|c|c|c|c|}
\hline \multirow{2}{*}{ Peubah } & \multirow{2}{*}{$\begin{array}{l}\text { Parameter } \\
\text { estimasi }\end{array}$} & \multicolumn{2}{|c|}{ Elastisitas } & \multirow{2}{*}{ Prob $>|\mathrm{T}|$} & \multirow{2}{*}{ Keterangan peubah } \\
\hline & & Jangka pendek & Jangka panjang & & \\
\hline Intercept & $2.886 .463,00$ & - & - & 0,018 & \\
\hline (HGTTIR / HGTTIR) & $128.519,00$ & 0,012 & 0,017 & 0,278 & $\begin{array}{l}\text { Rasio harga riil gabah di } \\
\text { tingkat petani di Indonesia }\end{array}$ \\
\hline HJTPIR & $-258,46$ & $-0,033$ & $-0,049$ & 0,276 & $\begin{array}{l}\text { Harga riil jagung di tingkat } \\
\text { produsen di Indonesia }\end{array}$ \\
\hline HUREIR & $-523,55$ & $-0,067$ & $-0,101$ & 0,014 & $\begin{array}{l}\text { Harga riil pupuk Urea di } \\
\text { Indonesia }\end{array}$ \\
\hline LKLSI & $-0,03$ & 0,000 & 0,000 & 0,466 & $\begin{array}{l}\text { Lag konversi lahan sawah di } \\
\text { Indonesia }\end{array}$ \\
\hline IPI & 4.123.558,00 & 0,509 & 0,765 & 0,000 & $\begin{array}{l}\text { Intensitas pertanaman di } \\
\text { Indonesia }\end{array}$ \\
\hline LLAPI & 0,34 & - & - & 0,030 & $\begin{array}{l}\text { Lag luas areal panen padi di } \\
\text { Indonesia }\end{array}$ \\
\hline Prob $>|F|=<.00$ & & $=0,9$ & & $\mathrm{Dw}=2,09$ & $\mathrm{Dh}=-0,29$ \\
\hline
\end{tabular}

Tabel 3. Hasil pendugaan parameter harga riil pembelian pemerintah (HPPGR)

\begin{tabular}{|c|c|c|c|c|c|}
\hline \multirow{2}{*}{ Peubah } & \multirow{2}{*}{$\begin{array}{l}\text { Parameter } \\
\text { estimasi }\end{array}$} & \multicolumn{2}{|c|}{ Elastisitas } & \multirow{2}{*}{ Prob $>|\mathrm{T}|$} & \multirow{2}{*}{ Keterangan peubah } \\
\hline & & Jangka pendek & Jangka panjang & & \\
\hline Intercept & $-154,10$ & - & - & 0,45 & \\
\hline HMBIR & 0,32 & 0,12 & 0,15 & 0,11 & $\begin{array}{l}\text { Harga riil beras impor } \\
\text { Indonesia }\end{array}$ \\
\hline GDPIR & $2,43 \times 10^{-13}$ & 0,30 & 0,37 & 0,05 & $\begin{array}{l}\text { Pendapatan nasional riil } \\
\text { Indonesia }\end{array}$ \\
\hline LERIR & 0,09 & 0,49 & 0,59 & 0,01 & $\begin{array}{l}\text { Lag nilai tukar rupiah thd US } \\
\text { dollar }\end{array}$ \\
\hline LHPPGR & 0,17 & - & - & 0,27 & $\begin{array}{l}\text { Lag harga riil gabah pembelian } \\
\text { pemerintah }\end{array}$ \\
\hline Prob $>|F|=0.04$ & \multicolumn{2}{|c|}{$\mathrm{R}^{2}=0,47$} & & $\mathrm{Dw}=2,38$ & $\mathrm{Dh}=-$ \\
\hline
\end{tabular}


Harga riil pembelian pemerintah (gabah/beras) dipengaruhi secara signifikan oleh peubah: harga riil beras impor Indonesia, pendapatan riil nasional Indonesia dan nilai tukar tahun sebelumnya. Harga riil pembelian pemerintah (gabah/beras) memiliki respon inelastis terhadap peubah perubahan harga riil beras impor Indonesia, pendapatan riil nasional Indonesia dan nilai tukar tahun sebelumnya dalam jangka pendek dan jangka panjang. Fenomena ini menunjukkan bahwa perubahan yang terjadi pada peubah harga riil beras impor Indonesia, pendapatan nasional riil dan juga nilai tukar, berdampak kecil terhadap perubahan harga riil pembelian pemerintah (gabah/beras). Hal ini diduga ada faktor eksternal lainnya seperti politik, yang menjadi pertimbangan bagi pemerintah dalam menentukan harga riil pembelian pemerintah (gabah/ beras).

Perubahan nama dari Harga Dasar Gabah (HDG) menjadi Harga Pembelian Pemerintah (HPP) ternyata mengubah fungsi "floor price" tersebut (Tabel 1). Hasil penelitian ini didukung oleh beberapa penelitian sebelumnya. Penelitian Maulana (2012) menyimpulkan bahwa harga HPP multikualitas beras tidak mempunyai dampak secara kuat terhadap peningkatan kualitas gabah di tingkat petani jika kebijakan HPP tunggal gabah masih tetap dipertahankan. Hal yang sama juga berlaku, jika HPP multikualitas hanya berlaku di gabah saja tanpa diikuti HPP multikualitas untuk beras, hanya akan mendorong perbaikan kualitas gabah, tanpa diikuti adanya peningkatan jumlah kualitas beras yang dihasilkan. Secara umum, jalinan harga antara pasar beras dan gabah bersifat asimetris. Ketika harga beras meningkat tajam tidak serta merta menyebabkan harga gabah di tingkat petani membaik secara nyata pula. Hal yang berbeda akan terjadi jika harga gabah meningkat secara signifikan maka perubahan ini hampir secara sempurna juga terjadi pada harga beras. Hal ini juga diduga menjadi penyebab tidak maksimalnya kalau HPP multikualitas hanya diterapkan pada beras sebagai instrumen tunggal dalam meningkatkan produksi beras berkualitas.

Masih sejalan dengan itu, penelitian Intan et al. (2013) menyebutkan bahwa rasio HPP untuk beras sangat tinggi dibanding dengan HPP GKG dan jauh lebih tinggi daripada rasio dengan HPP GKP. Fakta ini menunjukkan bahwa, walaupun harga aktual GKP dan GKG berada diatas HPP GKP dan GKG. Namun, persentase kenaikan harga aktual GKP dan GKG tersebut tidak dapat mengimbangi persentase kenaikan harga beras sehingga menyebabkan semakin besar kesenjangan yang terjadi antara harga beras dengan harga GKP dan GKG. Artinya, bahwa pada tahun 2011/2012 kenaikan HPP GKP, HPP GKG, maupun HPP Beras tersebut tidak pernah bisa menyamai harga aktual yang berlaku.

Adapun temuan Saputra et al. (2014) menegaskan bahwa pemerintah perlu mengkaji ulang kebijakan Harga Pembelian Pemerintah, agar dapat berjalan dengan efektif. Nilai elastisitas transmisi harga (Et) yang kurang dari satu $\left(\mathrm{E}_{\mathrm{t}}<1\right)$ mengindikasikan bahwa perubahan harga ditingkat konsumen yang terjadi tidak direspon secara baik oleh harga ditingkat produsen sehingga petani tidak merasakan dampak dari kenaikan harga beras yang terjadi di tingkat konsumen. Oleh karena itu, kebijakan HPP yang ditetapkan oleh pemerintah belum dapat dirasakan oleh petani atau tepatnya belum efektif.

\section{Implikasi Manjerial}

Harga riil pembelian pemerintah (gabah/beras) jika sejatinya merupakan "floor price" yang berfungsi untuk menjaga harga gabah/beras di tingkat petani dari kejatuhan harga pada saat over-supply (salah satunya akibat banyaknya jumlah beras impor di dalam negeri); maka akan menjadi intensif bagi petani untuk terus meningkatkan produktivitas padi.

\section{KESIMPULAN DAN SARAN}

\section{Kesimpulan}

Konversi lahan sawah di Indonesia tidak saja menurunkan kapasitas produksi padi yang ada. Namun, lebih jauh dari itu, konversi lahan sawah juga memengaruhi kebijakan harga pembelian pemerintah (gabah/beras). Konversi lahan sawah menuntut peningkatan jumlah beras impor sebagai konsekuensi berkurangnya ketersediaan beras domestik. Peningkatan jumlah beras impor berakibat terhadap harga riil eceran beras di dalam negeri. Untuk itu, pemerintah perlu menstabilkan harga riil gabah/beras di tingkat petani melalui penetapan harga riil pembelian pemerintah (gabah/beras). Namun, penetapan harga riil pembelian pemerintah (gabah/beras) dinilai belum mampu menjaga harga riil gabah di tingkat petani dari kejatuhan 
harga akibat meningkatnya volume beras impor karena pembentukan harga riil gabah di tingkat petani lebih dipengaruhi oleh mekanisme pasar yang ada.

\section{Saran}

Pemerintah perlu mengkaji ulang kebijakan harga riil pembelian pemerintah (gabah/beras) tersebut agar kembali kepada fungsi utamanya sebagai "floor price". Selain itu, pemerintah perlu mengimplementasikan harga pembelian pemerintah (HPP) multikualitas masing-masing untuk gabah dan beras, sehingga dapat menjadi insentif bagi petani untuk meningkatkan kualitas gabah dan juga beras mereka.

\section{UCAPAN TERIMA KASIH}

Ucapan terima kasih kepada para-pihak yang telah membantu dan memberikan sumbang-saran bagi kesempurnaan penyelesaian penelitian ini. Terutama kepada Dirjen DP2M Dikti Kementerian Riset, Teknologi, dan Pendidikan Tinggi, yang telah membiayai penelitian ini melalui skem Penelitian Desentralisasi Hibah Fundamental tahun 2016.

\section{DAFTAR PUSTAKA}

BPS. 2011. Statistik Indonesia 1990-2010. Jakarta: Badan Pusat Statistik.

Irawan B. 2005. Konversi lahan sawah: potensi dampak, pola pemanfaatannya, dan faktor determinan. Forum Penelitian Agro Ekonomi 23(1):1-18. https://doi.org/10.21082/fae.v23n1.2005.1-18.
Maulana, M. 2012. Prospek implementasi kebijakan Harga PembelianPemerintah (HPP) multikualitas gabah dan beras di Indonesia. Analisis Kebijakan Pertanian 10(3): 211-223. https:// doi.org/10.21082/akp.v10n3.2012.211-223.

Pindyck RS, Rubinfeld DL. 1998. Econometrics Models and Economic Forecasts. 4th Ed. New York: MacGraw-Hill Inc.

Purbiyanti E. 2013. Dampak konversi lahan sawah di Jawa dan luar Jawa terhadap ketersediaan dan akses pangan nasional [tesis]. Bogor: Magister Sains. Sekolah Pascasarjana, Institut Pertanian Bogor.

Purbiyanti E, Maryanah H, Mulyana E. 2013. Factors Influence Farmers' Decision To Convert Rainfed Lowland In South Sumatera, Indonesia. Di dalam: Proceedings of 2013 International Seminar on Climate Change and Food Security (ISCCFS). Palembang, South Sumatra-Indonesia, 24-25 October, 2013.

Saputra A, Arifin B, Kasymir E. 2014. Analisis kausalitas harga beras, harga pembelian pemerintah (Hpp) dan inflasi serta efektivitas kebijakan HPP di Indonesia. Jurnal Ilmu-Ilmu Agribisnis 2(1):24-31.

Simatupang P. 2003 Jan 28. Harga dasar gabah. Suara Pembaruan, 28 Januari 2003.

Sitepu RK, Sinaga BM. 2006. Aplikasi Model Ekonometrika: Estimasi, Simulasi dan Peramalan Menggunakan Program SAS. Bogor: Prodi Ilmu Ekonomi Pertanian, SPs IPB,

Sumaryanto S, Friyatno, Irawan B. 2006. Konversi Lahan Sawah ke Penggunaan Nonpertanian dan Dampak Negatifnya. Di dalam: Prosiding Seminar Nasional Multifungsi Lahan Sawah. 